\title{
Design, Development, and Performance Evaluation of Solar Heating System for Disinfection of Domestic Roof-Harvested Rainwater
}

\author{
O. A. Akintola ${ }^{1}$ and A. Y. Sangodoyin ${ }^{2}$ \\ ${ }^{1}$ National Horticultural Research Institute of Nigeria, Secretariat Post Office, P.O. Box 29662, Idi-Ishin, Ibadan, Nigeria \\ ${ }^{2}$ Department of Agricultural and Environmental Engineering, Faculty of Technology, University of Ibadan, Ibadan, Nigeria
}

Correspondence should be addressed to O. A. Akintola; akinbolanle97@yahoo.co.uk

Received 9 October 2014; Accepted 11 December 2014

Academic Editor: Erick R. Bandala

Copyright (C) 2015 O. A. Akintola and A. Y. Sangodoyin. This is an open access article distributed under the Creative Commons Attribution License, which permits unrestricted use, distribution, and reproduction in any medium, provided the original work is properly cited.

\begin{abstract}
A box-type solar heater was designed, constructed, and used to determine the effect of solar heating on quality of domestic roofharvested rainwater (DRHRW). During testing, naturally contaminated DRHRW was harvested in Ibadan, Nigeria, and released into the system at $93.96 \mathrm{Lh}^{-1}\left(2.61 \times 10^{-5} \mathrm{~m}^{3} \mathrm{~s}^{-1}\right)$ in a continuous flow process. Water temperatures at inlet, within the heating chamber, and at outlet from the heating chamber and solar radiation were monitored at 10 min interval. Samples were collected at both inlet to and outlet from the heating chamber at $10 \mathrm{~min}$ interval for microbiological analysis. The highest plate stagnation temperature, under no-load condition, was $100^{\circ} \mathrm{C}$. The solar water heater attained a maximum operational temperature of $75^{\circ} \mathrm{C}$ with 89.6 and $94.4 \%$ reduction in total viable count and total coliform count, respectively, while Escherichia coli and Staphylococcus aureus were completely eradicated at this temperature. The solar heater developed proved to be effective in enhancing potability of DRHRW in Ibadan, Nigeria. This may be an appropriate household water treatment technology for developing countries, hence, a way of resolving problem of low quality water for potable uses.
\end{abstract}

\section{Introduction}

Good quality water is gradually getting beyond the reach of average households in developing countries [1]. This is attributed to low income earnings vis-à-vis the ever increasing cost of other sources of energy for water disinfectant such as kerosene and firewood. The use of chloride solution concentrate has been reported to be an effective means of cleaning vessels for water disinfection and prevention of waterborne diseases $[2,3]$. It however does not prevent recontamination. It was therefore suggested that efforts should be made to protect water after treatment up until the point of use [4]. To achieve this, WHO [5] suggested the use of residual chlorine of between 0.2 and $0.5 \mathrm{mg} / \mathrm{L}$. The option is viable in places where public tap supply is in operation. This is far from reality in developing nations due to the collapse of public water supply systems.

Most rural and semiurban settlements do not have the "privilege" of being connected to national electricity grid either. Where they are connected, the erratic supply makes it imperative for cheaper and more reliable source of energy that could be used especially for water pasteurization to be sourced. Solar energy is a free, inexhaustible, and environment-friendly resource $[6,7]$. It is estimated that one billion people worldwide do not have access to treated drinking water [8]. Harvesting of solar energy and its use may be a way out of this crisis, not only because of its availability in Nigeria, but mainly due to its relative safety as well, compared to the use of fossil fuels [9].

Solar water heater can be used to pasteurize water thereby destroying harmful food-water microbes including bacteria and viruses when heated to temperatures of about $65^{\circ} \mathrm{C}[10$, 11]. Countries that could be considered as having potential for solar cooking must satisfy certain criteria, some of which include high insolation, fuel wood shortages, low per capital income, and high population density. Similarly, the estimated number of potential beneficiaries must be high. These conditions are satisfied by Nigeria with a ranking of five 
(5) in the list of countries with the highest potential benefit from solar cooking [12].

Contamination of surface and ground waters by pathogens and chemicals tends to make domestic roofharvested rainwater an alternative. In the study environment, most households are in the habit of harvesting and storing rainwater in jars and cisterns to supplement other sources of potable water during the raining season. Previous studies have reported on the poor microbial quality of DRHRW [1318]. This will likely become worse if stored for a long period. However, a small increase in temperature can improve the solar disinfection effectiveness for certain microbial strains [19]. The populace is constantly faced with the problem of high cost of cooking fuels as well as diminishing wood supply. There is also the problem of overdependence on wood, leading to deforestation and its attendant problems of erosion and global warming. Other alternatives such as the use of kerosene, gas, and electricity are unattractive because they are costly, unavailable, or unreliable. Hence, this study investigated the use of locally available materials to develop solar heating system that can be used to improve the quality of domestic roof-harvested rainwater in Nigeria and other developing countries.

\section{Material and Methods}

The study was conducted at the University of Ibadan, Ibadan, Nigeria (latitude $7^{\circ} 26^{1} \mathrm{~N}$; longitude $3^{\circ} 54^{1} \mathrm{E}$ ). Solar water heating system was designed to handle continuous flow of water with a mean design temperature of $65^{\circ} \mathrm{C}$. Experimental arrangement of the solar heater for temperature measurements is shown in Figure 1. The solar water heater developed and used in this work has five important components, namely, the outer box, the inner box, double-walled glass cover, reflector lid, and absorber plate. Due to its local availability in some part of southwestern Nigeria and low thermal conductivity, coconut fiber was used as lagging material. This was introduced to fill the space between the inner and outer boxes such that there is $100 \mathrm{~mm}$ thickness of insulating materials all around the inner box and between the inner and outer box. The insulating material was closely packed together at about $95.58 \mathrm{~kg} \mathrm{~m}^{-3}$ density which is comparable to the average density of $112 \mathrm{~kg} \mathrm{~m}^{-3}$ recommended by Baryeh [20]. The space housing the insulating materials was then sealed up with four pieces of plywood noggins.

The solar water heating system was evaluated in an open field belonging to the Nigerian Micrometeorological Experiments (NIMEX) Research Group, Department of Physics, University of Ibadan, Nigeria, for eleven days. The meteorological instruments used comprised both slow and fast responses. These measured mean and turbulent parameters in the surface layers simultaneously. A $15 \mathrm{~m}$ mast was set up to measure the profiles of the mean wind speed at $0.7,1.2,2.2,3.3$, $5.2,7.2,10.2$, and $14.8 \mathrm{~m}$ (the mean wind direction is inclusive only at the $14.8 \mathrm{~m}$ height) and air temperature (wet and dry bulb) at $0.9,4.9$, and $10.0 \mathrm{~m}$. The same mast also supported radiation sensors for both global and net radiation at $1.5 \mathrm{~m}$. The slow measurements were controlled by the use of two Campbell CR10X data loggers which sampled the data every

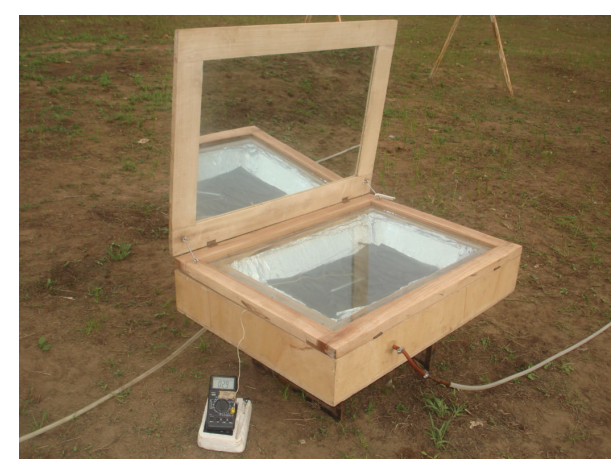

FIGURE 1: Experimental arrangement for temperature measurements (collector area, $0.47 \mathrm{~m}^{2}$ ).

1 second and subsequently stored them as 1-minute averaged value. A list of all the meteorological equipment used in this study is contained in Table 1. The location was obstructionfree and free of shadows. The arrangement was to monitor the rise in temperature of the absorber plate under no-load condition. Hence, the maximum temperature attainable at a given solar radiation on a particular day can be determined. Similarly, a pyranometer was used from the same station to monitor solar radiation.

From standard procedure, thermal efficiency of a solar water heater or cooker is determined from water heating test using the relationship

$$
\eta=\frac{\left(M_{w} C_{w}+M_{c u} C_{c u}\right) \sum \Delta T}{I A \Delta t},
$$

where $\eta=$ thermal efficiency (\%), $M_{w}=$ mass of water $(\mathrm{Kg}), M_{c u}=$ mass of the copper pipe $(\mathrm{Kg}), C_{w}=$ specific heat capacity of water $\left(4200 \mathrm{~J} \mathrm{Kg}^{-1}{ }^{\circ} \mathrm{K}^{-1}\right), C_{c u}=$ specific heat capacity of copper pipe $\left(400 \mathrm{~J} \mathrm{Kg}^{-1}{ }^{\circ} \mathrm{K}^{-1}\right), I=$ total solar radiation $\left(\mathrm{W} \mathrm{m}^{-2}\right), A=$ area of absorber plate $\left(\mathrm{m}^{2}\right), \Delta T=$ difference in temperature $\left({ }^{\circ} \mathrm{C}\right)$, and $\Delta t=$ difference in time (seconds).

A typical box-type heater requires adjustment every 15 to 30 min or when shadow appears on the absorber plate. The solar water heater was designed such that the orientation of the reflector lid (when operated) is facing the sunset (west). This was found to be representative of local conditions, since the users will not likely have the time to stay with the system and be turning it every 15 to $30 \mathrm{~min}$. The limitation of this fixed condition is that the system will only operate effectively between the hours of 11:30 a.m. and 4:30 p.m. on clear/sunny days. However, manual azimuth adjustment will increase its efficiency. Readings were monitored and recorded at $10 \mathrm{~min}$ interval, similar to the method used by Mahavar et al. [21]. The highest temperature taken for the day was noted as the stagnation temperature.

Most of the studies reported in the literature on solar disinfection used water with laboratory grown organisms subjected to simulated solar irradiation [17, 22, 23]. Bacteria inactivation rate was reported to be slower for naturally occurring organisms compared with laboratory grown organisms [17]. In this study, naturally contaminated DRHRW in Ibadan, 
TABLE 1: List of meteorological instruments used in this study.

\begin{tabular}{lcccc}
\hline Parameter & Device and model & Manufacturer & Accuracy & Number \\
\hline Wind speed & $\begin{array}{c}\text { Cup anemometer } \\
\text { A101ML/A100L2 }\end{array}$ & Vector Instruments & Distance const. $2.3 \mathrm{~m}$ & 10 \\
\hline Wind direction & Wind vane W200P & Vector Instruments & Distance const. $2.3 \mathrm{~m}$ & 2 \\
\hline $\begin{array}{l}\text { Air temperature (wet and } \\
\text { dry bulb) }\end{array}$ & $\begin{array}{c}\text { Frankenberger } \\
\text { psychrometer }\end{array}$ & Theodor Friedrichs & $\pm 0.05^{\circ} \mathrm{C}$ & 5 \\
\hline $\begin{array}{l}\text { Surface temperature } \\
\text { Infrared pyrometer } \\
\text { KT1582D }\end{array}$ & Heitronics & $\pm 0.05^{\circ} \mathrm{C}$ & 1 \\
\hline Global radiation & Pyranometer SP-LITE & Kipp \& Zonen & $80 \mu \mathrm{N} / \mathrm{Wm}^{2}$ & 1 \\
\hline Net radiation & $\begin{array}{c}\text { Net radiometer (REBS) } \\
\text { Q7, NR-LITE }\end{array}$ & Campbell/Kip \& Zonen & $+9.6(-11.9)$ & 2 \\
\hline
\end{tabular}

Source: NIMEX Research Group, Department of Physics, University of Ibadan, Nigeria.

Nigeria, was harvested and released into the system at $2.61 \times$ $10^{-5} \mathrm{~m}^{3} \mathrm{~s}^{-1}\left(93.96 \mathrm{Lh}^{-1}\right)$ in a continuous flow process. Water temperatures at the inlet, within the heating chamber, and at the outlet to the heating chamber and solar radiation were monitored at $10 \mathrm{~min}$ interval.

Samples were also collected into McCartney bottles at both the inlet to and the outlet from the heating chamber at 10 min interval for microbiological analysis. All the samples were analyzed immediately.

The total viable count was carried out by means of the standard plate count technique using plate count agar. Dilutions of water samples in buffered peptone water were inoculated by putting $1 \mathrm{~mL}$ into each $10 \mathrm{~mL}$ molten standard plate count agar in McCartney bottles. After thorough mixing, these were poured into sterile Petri dishes and incubated for 48 hours at $22^{\circ} \mathrm{C}$. Petri dishes from dilutions counting 50 discrete colonies were counted and the results expressed as the number of bacteria colonies per millilitre. The isolates were further identified using their macroscopic, cultural, physiological, and biochemical characteristics. Presumptive coliform test for the detection of coliform was done after the methods stated in [24]. MacConkey broth was used for the presumptive tests. Inoculated tubes of MacConkey broth were incubated at $44^{\circ} \mathrm{C}$ for 2 hours. Positive presumptive tests were confirmed using eosin methylene blue agar. Colonies with characteristic growth were reinoculated in the tubes of MacConkey broth. Growth characteristics in methylene blue as well as reactions to indole, methyl red, Voges-Proskauer, and citrate utilization tests were used as confirmation of the presence of Escherichia coli. Mannitol salt agar was used for Staphylococcus aureus. The chemicals used in the study were of analytical grade and the preparation was done according to test guidelines ([24-26], API 20E and API 20NE bioMerieux, France).

\section{Results and Discussion}

3.1. Main Design. The schematic drawing for the design and fabrication of a flat plate collector, box solar water heater is presented in Figure 2. The design of the system is made such that the temperature is used up as soon as it is being built up by the incoming water that is constantly flowing through it (which is at a lower temperature, relative to the temperature within the heating chamber). The procedure for the design and fabrication of the solar water heater is presented in Figure 2.

\subsection{Design Conditions. Design conditions are as follows:}

(i) transparent surface area $=0.84 \mathrm{~m} \times 0.56 \mathrm{~m}=0.47 \mathrm{~m}^{2}$;

(ii) absorber plate $=0.3 \mathrm{~m} \times 0.6 \mathrm{~m}$ black coated (front and back); aluminium sheet $1.4 \mathrm{~mm}$ gauge was used as the absorber plate;

(iii) absorber pipe $=4.34 \mathrm{~m}$ length and $0.0064 \mathrm{~m}$ diameter, black coated, was used as the absorber/conveyance pipe.

Aluminium plate and copper pipe were used because of their high thermal conductivity, low weight per unit area, availability, affordability, workability, and good resistance to corrosion. Aluminium is nontoxic and hence it is used in cooking ware. Corrosion of copper is most often associated with soft, acidic waters with $\mathrm{pH}$ below 6.5 [5]. It is only toxic at elevated concentration. It is also a micronutrient needed by the body with a dietary value of $2 \mathrm{mg} / \mathrm{kg}$ [27]. Domestic roof-harvested rainwater used in this study has mean values of $\mathrm{pH}$ ranging from 6.8 to 7.6, irrespective of roof types and those that were collected directly without contact with roof materials. Also, a contact time of $7 \mathrm{~min}$ and a temperature of less than $80^{\circ} \mathrm{C}$ are not sufficient to leach copper quantity that will cause toxic effect.

Aremu [28] suggested that the base area should be smaller than the surface area and that the solar water heater should be shallow enough so as to avoid side shading effect. For maximum concentration at the base of the solar water heater, a side inclination of $35^{\circ}$ was used.

3.2.1. Inner Box. Dimensions of the inner box are as follows:

(i) surface area $=0.84 \mathrm{~m} \times 0.56 \mathrm{~m}$;

(ii) base area $=0.6 \mathrm{~m} \times 0.3 \mathrm{~m}$;

(iii) sides $=0.56 \mathrm{~m} \times 0.30 \mathrm{~m} \times 0.17 \mathrm{~m}$ and $0.84 \mathrm{~m} \times 0.60 \mathrm{~m}$ $\times 0.17 \mathrm{~m}$ (in pairs).

The inner box was lagged $0.10 \mathrm{~m}$ on all sides. 


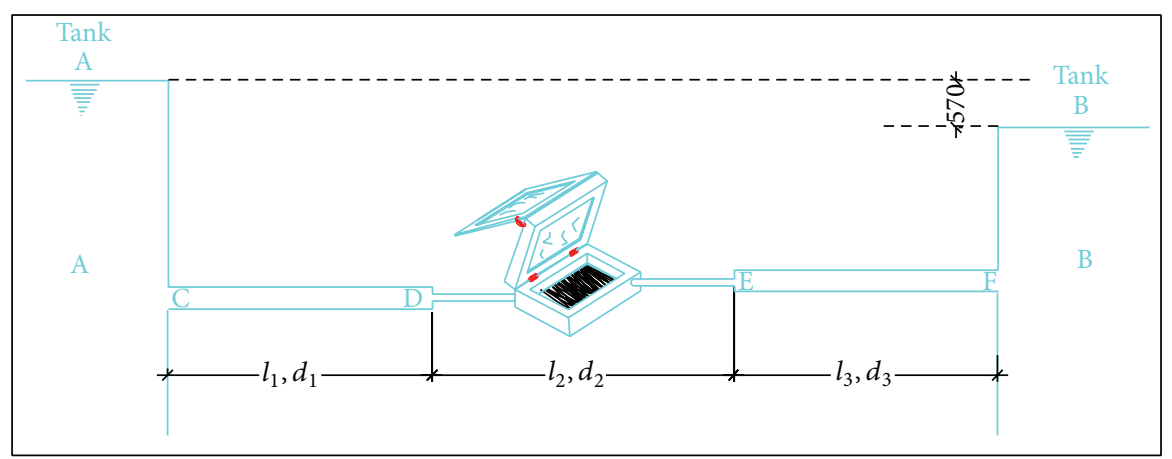

FIGURE 2: Schematic drawing of the solar heating system.

\subsubsection{Outer Box}

Dimension of the outer box $=1.07 \mathrm{~m} \times 0.76 \mathrm{~m} \times 0.20 \mathrm{~m}$.

A reflector lid of dimension equal to the area of the lid was attached to one side of the lid, with a mirror of $0.91 \mathrm{~m} \times$ $0.61 \mathrm{~m}$, so it may act as a booster to maximize solar radiation transfer into the box.

For a flat plate collector, applying the First Law of Thermodynamics (conservation of energy),

Output energy $\left(Q_{a}\right)=$ Input energy $\left(Q_{u}\right)$

$$
\text { - the losses (at equilibrium) }\left(Q_{l}\right) \text {. }
$$

Since the average energy from the sun is constant on a very clear day for a given locality, the energy transferred can be optimized by minimizing the heat loss $\left(Q_{l}\right)$ component.

For a double cover arrangement, Stout [29] reported that the energy input into the collector when the sun is at the zenith and its radiation is at right angle is $1 \mathrm{Kwm}^{-2}$ given a cloudless sky and clear air. Approximately $12 \%$ of the energy reaching each cover is reflected for each of the glass covers in the double cover arrangement. Hence, for a solar water heater of effective surface area of $0.47 \mathrm{~m}^{2}$,

$$
Q_{u}=1000 \mathrm{Wm}^{-2} \times 0.88 \times 0.88 \times 0.47 \mathrm{~m}^{2}=363.97 \mathrm{~W} .
$$

If cleaned and set at the correct angle, the reflector lid (booster) can reflect about $25 \%$ of the available insolation into the system. Hence,

$$
Q_{u}=363.97+(25 \% \text { of } 363.97)=454.96 \mathrm{~W} .
$$

3.3. Heat Losses. Total heat losses from the system are the sum total of heat losses from the bottom $\left(Q_{b}\right)$, sides $\left(Q_{s}\right)$, and covers $\left(Q_{c}\right)$ given as

$$
Q_{l}=Q_{b}+Q_{s}+Q_{c}
$$

where

$$
\begin{aligned}
& Q_{l}=\text { heat loss (overall, } \mathrm{W} \text { ), } \\
& Q_{b}=\text { heat loss from the bottom }(\mathrm{W}),
\end{aligned}
$$

$Q_{s}=$ heat loss from the sides $(\mathrm{W})$,

$Q_{c}=$ heat loss from the cover $(\mathrm{W})$,

$$
Q_{b}=U_{b} A \Delta T,
$$

where

$$
U_{b}=\frac{K}{L}
$$

$K=$ thermal conductivity of lagging material = $0.0295 \mathrm{~W} \mathrm{~m}^{-1}{ }^{\circ} \mathrm{C}^{-1}$,

$L=$ thickness of lagging material $=0.10 \mathrm{~m}$,

$A=$ base area $0.60 \mathrm{~m} \times 0.30 \mathrm{~m}=0.18 \mathrm{~m}^{2}$,

$$
Q_{s}=U_{b} A_{s} \Delta T,
$$

$A_{s}=$ area of the sides $\left(\mathrm{m}^{2}\right)$,

$$
Q_{c}=U_{t} A_{c} \Delta T Q_{c}
$$

From Duffie and Beckman [30],

$$
\begin{aligned}
U_{t}= & \left(\left[\frac{N}{\left(344 / T_{p}\right)}\left[\frac{T_{p}-T_{a}}{N+F}\right]^{0.31}+\frac{1}{h_{w}}\right]^{-1}\right. \\
& \left.+\sigma\left(T_{p}+T_{a}\right)\left(T_{p}^{2}+T_{a}^{2}\right)\right) \\
& \times\left(\left[\varepsilon_{p}+0.0425 N\left(1-\varepsilon_{p}\right)\right]^{-1}\right. \\
& \left.+\left[\frac{(2 N+F-1)}{\varepsilon_{g}}\right]-N\right)^{-1}
\end{aligned}
$$

where

$h_{w}=$ wind heat transfer coefficient $=5.7+3.8 \mathrm{~V}$,

$N=$ number of glass covers (2),

$\varepsilon_{g}=$ emittance of glass (0.88), 

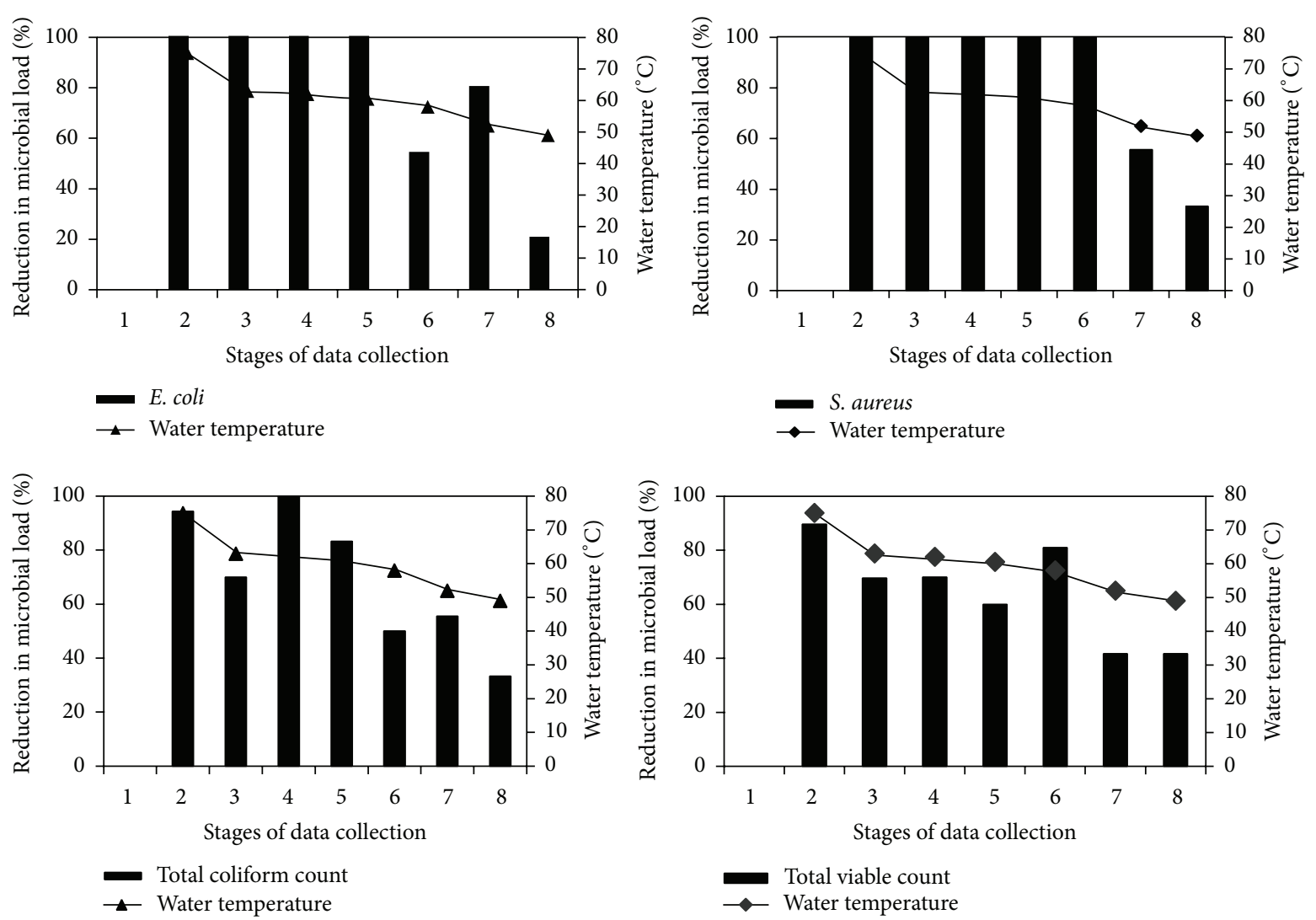

FIGURE 3: Variation in percentage reduction in microbial load with change in water temperature as a result of solar disinfection process. (1) The bar charts corresponded with the labels to the left, representing percentage reduction in microbial load. (2) The line corresponded with the labels to the right, representing water temperatures. (3) Stages of data collection refer to variation in water temperature (measured at the outlet to the heating chamber) ranging from 49 to $75^{\circ} \mathrm{C}$ and the corresponding percentage reduction in microbial load. Stages $2,3,4,5,6,7$, and 8 correspond with $75,63,62,60.5,58,52$, and $49^{\circ} \mathrm{C}$, respectively.

$$
\begin{aligned}
& \varepsilon_{p}=\text { emittance of plate }(0.95), \\
& T_{p}=\text { plate temperature. }
\end{aligned}
$$

Total heat loss was calculated to be $77.04 \mathrm{~W}$.

Hence, output energy

$$
Q_{a}=454.96 \mathrm{~W}-77.04 \mathrm{~W}=377.92 \mathrm{~W} \text {. }
$$

The user can reckon on a total of $377.92 \mathrm{~W}$, taking the losses into consideration. $1.16 \mathrm{~W}$-hours is needed to heat up 1 litre of water by $1^{\circ} \mathrm{C}[28]$. To heat up from ambient temperature of $30^{\circ} \mathrm{C}$ to $65^{\circ} \mathrm{C}$, that is, temperature rise of $35^{\circ} \mathrm{C}, 1.16 \mathrm{Wh} \times 35=$ $40.60 \mathrm{Wh}$. Hence, $40.60 \mathrm{Wh}$ heat is required which will take $40.60 \mathrm{Wh} / 377.92 \mathrm{~W}$, that is, $0.11 \mathrm{hr}$ (6.45 minutes). The highest stagnation temperature recorded was $100^{\circ} \mathrm{C}$.

3.4. Flow Rate Determination. From Figure 2, diameter $\left(d_{1}\right)$ $=0.0127 \mathrm{~m}=d_{3}, d_{2}=0.0064 \mathrm{~m}$, length $\left(l_{1}\right)=3.8 \mathrm{~m}=l_{3}$, and $l_{2}=4.34 \mathrm{~m}$.

Neglecting form losses,

$$
\text { discharge } Q=Q_{1}=Q_{2}=Q_{3} \text {. }
$$

The discharge through the system was then calculated to be $93.96 \mathrm{Lh}^{-1}$. To ensure the detention period of about 7 minutes within the solar panel, a serpentine or sinusoidal shape was assumed for the copper pipe used. On a clear day, the system can work effectively for about 4 hours on average, treating about $375.84 \mathrm{~L}$ of water. This amount should be enough to meet the minimum volume of $7.5 \mathrm{~L}$ per capital per day recommended by WHO [5] for a family of six, for one week.

3.5. Evaluation of the Solar Water Heater. The effect of temperature on microbial load of treated water with solar water heater is presented in Table 2 while the percentage reductions in microbial load due to solar disinfection are presented in Figure 3. The mean thermal efficiency of the system is $54 \%$. The solar water heating system showed great potential for water pasteurization. It attained a maximum operating temperature of $75^{\circ} \mathrm{C}$. At this temperature, a reduction of $89.6 \%$ in total viable count and $94.4 \%$ in total coliform count was achieved, while Escherichia coli and $S$. aureus were completely eradicated. At temperatures as low as $49^{\circ} \mathrm{C}$, the heating system was still able to achieve 41.7, 33.3, 20.0, and $33.3 \%$ reduction in microbial load, respectively, for total viable count, total coliform count, E. coli, and S. aureus. Uzel et al. [31] had reported that temperature of about 60 to $70^{\circ} \mathrm{C}$ can prevent permanent colonization of Legionella spp. 
TABLE 2: Effect of temperature on microbial load of treated water with solar water heater.

\begin{tabular}{|c|c|c|c|c|c|c|c|c|c|c|}
\hline \multirow{3}{*}{ Sample } & \multirow{3}{*}{ Inlet water temperature $\left({ }^{\circ} \mathrm{C}\right)$} & \multirow{3}{*}{ Outlet water temperature $\left({ }^{\circ} \mathrm{C}\right)$} & \multicolumn{8}{|c|}{ Microbial load cfu $/ \mathrm{mL} \times 10^{4}$} \\
\hline & & & \multicolumn{2}{|c|}{ Total viable count } & \multicolumn{2}{|c|}{ Total coliform count } & \multicolumn{2}{|c|}{ E. coli } & \multicolumn{2}{|c|}{ S. aureus } \\
\hline & & & Inlet & Outlet & Inlet & Outlet & Inlet & Outlet & Inlet & Outlet \\
\hline $\mathrm{A} 1$ & 32.0 & 75.0 & 48 & 5 & 18 & 1 & 10 & nd & 9 & nd \\
\hline $\mathrm{A} 2$ & 34.0 & 63.0 & 33 & 10 & 10 & 3 & 5 & nd & 10 & nd \\
\hline A3 & 34.0 & 62.0 & 30 & 9 & 15 & nd & 9 & nd & 7 & nd \\
\hline A4 & 32.0 & 60.5 & 48 & 19 & 18 & 3 & 10 & nd & 9 & nd \\
\hline A5 & 33.0 & 58.0 & 63 & 12 & 20 & 10 & 13 & 6 & 10 & nd \\
\hline A6 & 32.0 & 52.0 & 48 & 28 & 18 & 8 & 10 & 2 & 9 & 4 \\
\hline A7 & 32.0 & 49.0 & 48 & 28 & 18 & 12 & 10 & 8 & 9 & 6 \\
\hline
\end{tabular}

nd: not detected.

McGuigan et al. [32] also observed that children (5 to 16 years of age) who stored their drinking water in 1.5-litre plastic bottles that were placed in direct sunlight for continuous periods of not less than six hours in Kenya experienced a 9\% reduction in incidences of severe diarrhea over three months' duration of the trial, compared with the control group. Meera and Ahammed [17], Heaselgrave et al. [22], and McGuigan et al. [23] reported the effectiveness of solar disinfection (SODIS) in disinfecting water contaminated with total coliforms: cyst of Giardia muris and oocysts of Cryptosporidium parvum poliovirus and Acanthamoeba polyphaga, respectively, at temperatures of 40 to $55^{\circ} \mathrm{C}$.

3.6. Cost Implications of the Designed Solar Heating System. The averagecost of fabricating a unit of the solar water heater at the time of this research was $\$ 32,161.76$ (\$201.01) at the rate of $\$ 1=\mathrm{N} 160$. This amount is equivalent to the cost of purchasing $402.02 \mathrm{~L}$ of bottled water in Ibadan, Nigeria, where the experiment was conducted. A bottle of $1.5 \mathrm{~L}$ of water is being sold for about $\mathrm{N} 120$ (\$0.75) in the area at the time of the experimentation. It would take the developed solar heating system 2 clear/sunny days to treat 402.02 L. Hence, the cost of constructing this system would be recovered in only 2 clear/sunny days.

\section{Conclusion}

An appropriate low cost solar heating system was developed and evaluated as a way of reducing microbiological contamination of domestic roof-harvested rainwater. The solar water heater recorded a maximum operating temperature of $75^{\circ} \mathrm{C}$ with 89.6 and $94.4 \%$ reduction in total viable count and total coliform count, respectively, while E. coli and S. aureus were completely eradicated at this temperature. The thermal efficiency of the solar heater was $54.0 \%$. The DRHRW in Ibadan, Nigeria, contains some contaminants and is therefore not safe for potable uses without treatment. The solar heater developed proved to be effective in improving the quality of DRHRW. It is however not recommended for use in disinfecting water with $\mathrm{pH}$ less than 6.5.

\section{Conflict of Interests}

The authors declare that there is no conflict of interests regarding the publication of this paper.

\section{Acknowledgment}

The authors acknowledge Nigerian Micrometeorological Experiments (NIMEX) Research Group, Department of Physics, University of Ibadan, Ibadan, Nigeria, for access to their meteorological facilities during evaluation of the developed solar heating system.

\section{References}

[1] InterAction Council, The Global Water Crisis: Addressing an Urgent Security Issue, Papers for the InterAction Council, 20112012, Series Editor: T. S. Axworthy, edited by H. Bigas, T. Morris, B. Sandford and Z. Adeel, 2012.

[2] V. M. Walden, E.-A. Lamond, and S. A. Field, "Container contamination as a possible source of a diarrhoea outbreak in Abou Shouk camp, Darfur province, Sudan," Disasters, vol. 29, no. 3, pp. 213-221, 2005.

[3] A. Steele, B. Clarke, and O. Watkins, "Impact of jerry can disinfection in a camp environment-experiences in an IDP camp in Northern Uganda," Journal of Water and Health, vol. 6, no. 4, pp. 559-564, 2008.

[4] T. F. Clasen and A. Bastable, "Faecal contamination of drinking water during collection and household storage: the need to extend protection to the point of use," Journal of Water and Health, vol. 1, no. 3, pp. 109-115, 2003.

[5] WHO, Guidelines for Drinking Water Quality. Volume 1: Recommendations, World Health Organization, Geneva, Switzerland, 3rd edition, 2008, http://www.who.int/water_sanitation_health/dwq/fulltext.pdf.

[6] K. Gairaa and Y. Bakelli, "Solar energy potential assessment in the Algerian south area: case of Ghardaïa region," Journal of Renewable Energy, vol. 2013, Article ID 496348, 11 pages, 2013.

[7] D. A. Hagos, A. Gebremedhin, and B. Zethraeus, "Solar water heating as a potential source for inland Norway energy mix," Journal of Renewable Energy, vol. 2014, Article ID 968320, 11 pages, 2014. 
[8] S. A. Mbogo, "A novel technology to improve drinking water quality using natural treatment methods in rural Tanzania," Journal of Environmental Health, vol. 70, no. 7, pp. 46-50, 2008.

[9] M. Rabbani, Y. Rahimi, S. M. Kazemi, and M. Samavati, "Satisfying the energy demand of a rural area by considering the investment on renewable energy alternatives and depreciation costs," Journal of Renewable Energy, vol. 2014, Article ID 907592, 8 pages, 2014.

[10] C. A. Braga, G. Armond, V. G. M. Joseph et al., "Automated solar heating to control pathogens in irrigation water," Revista Brasileira de Engenharia Agrícola e Ambiental, vol. 5, no. 2, pp. 327-331, 2001.

[11] M. A. S. Tanaka, M. I. Ito, C. A. S. Braga, and G. Armond, "Solar heating of water for controlling phytopathogenic microorganisms, Solar thermal treatment of water to control pathogens," Fitopatologia Brasileira, vol. 28, no. 4, pp. 386-393, 2003.

[12] B. L. Blum, “The case for solar cooking," Prepared for UNESCO science sector solar decade programme, 1997.

[13] M. I. Yaziz, H. Gunting, N. Sapari, and A. W. Ghazali, "Variations in rainwater quality from roof catchments," Water Research, vol. 23, no. 6, pp. 761-765, 1989.

[14] P. Vasudevan and N. Pathak, Water Quality in Domestic Roofwater Harvesting Systems (DRWH). Report.C3: Water Quality in DRWH, IIT Delhi, 2000.

[15] A. Plazinska, "Rainwater: quality issues," in Proceedings of the 10th International Rainwater Catchment Systems Conference, pp. 129-132, Mannheim, Germany, September 2001.

[16] G. Simmons, V. Hope, G. Lewis, J. Whitmore, and W. Gao, "Contamination of potable roof-collected rainwater in Auckland, New Zealand," Water Research, vol. 35, no. 6, pp. 1518-1524, 2001.

[17] V. Meera and M. M. Ahammed, "Solar disinfection for household treatment of roof-harvested rainwater," Water Science and Technology: Water Supply, vol. 8, no. 2, pp. 153-160, 2008.

[18] O. A. Akintola, A. Y. Sangodoyin, and O. S. Adebayo, "Microbiological qualities of domestic roof-harvested rainwater in selected locations in Nigeria," Journal of Biological and Chemical Research, vol. 30, no. 2, pp. 849-860, 2013.

[19] M. Berney, H.-U. Weilenmann, A. Simonetti, and T. Egli, "Efficacy of solar disinfection of Escherichia coli, Shigella flexneri, Salmonella Typhimurium and Vibrio cholerae," Journal of Applied Microbiology, vol. 101, no. 4, pp. 828-836, 2006.

[20] E. A. Baryeh, "Thermal conductivities of some West African fibres," The Agricultural Engineer, vol. 40, no. 1, pp. 10-14, 1985.

[21] S. Mahavar, N. Sengar, P. Rajawat, M. Verma, and P. Dashora, "Design, development and performance studies of a novel single family solar cooker," Renewable Energy, vol. 47, pp. 67-76, 2012.

[22] W. Heaselgrave, N. Patel, S. Kilvington, S. C. Kehoe, and K. G. McGuigan, "Solar disinfection of poliovirus and Acanthamoeba polyphaga cysts in water-a laboratory study using simulated sunlight," Letters in Applied Microbiology, vol. 43, no. 2, pp. 125130, 2006.

[23] K. G. McGuigan, F. Méndez-Hermida, J. A. Castro-Hermida et al., "Batch solar disinfection inactivates oocysts of Cryptosporidium parvum and cysts of Giardia muris in drinking water," Journal of Applied Microbiology, vol. 101, no. 2, pp. 453-463, 2006.

[24] APHA-American Public Health Association, Standard Methods for the Examination of Water and Wastewater, Washington, DC, USA, 19th edition, 1995.
[25] J. G. Collee, J. P. Dugid, A. G. Fraser, and B. P. Marmion, Practical Microbiology, Churchill Livingstone, Edinburgh, UK, 13th edition, 1989.

[26] E. W. Koneman, S. D. Allen, W. M. Janda, P. C. Schreckenberger, and W. C. Winn Jr., Colour Atlass and Textbook of Diagnostic Microbiology, Lippincott, Philadelphia, Pa, USA, 5th edition, 1997.

[27] R. Danzeisen, M. Araya, B. Harrison et al., "How reliable and robust are current biomarkers for copper status?" British Journal of Nutrition, vol. 98, no. 4, pp. 676-683, 2007.

[28] A. K. Aremu, The development, evaluation and parametric modelling of box type solar cooker [Ph.D. thesis], Department of Agricultural and Environmental Engineering, University of Ibadan, Ibadan, Nigeria, 2004.

[29] B. A. Stout, Handbook of Energy for World Agriculture, Elsevier Science, London, UK, 1990.

[30] J. A. Duffie and W. A. Beckman, Solar Energy Thermal Processes, John Willey and Sons Inc, New York, NY, USA, 1974.

[31] A. Uzel, F. Uçar, and E. E. Hameş-Kocabaş, "Prevalence of Legionella pneumophila serogroup 1 in water distribution systems in Izmir province of Turkey," APMIS, vol. 113, no. 10, pp. 664-669, 2005.

[32] K. G. McGuigan, J. M. Joyce, R. M. Conroy, J. B. Gillespie, and M. Elmore-Meegan, "Solar disinfection of drinking water contained in transparent plastic bottles: characterising the bacterial inactivation process," Journal of Applied Microbiology, vol. 84, pp. 1138-1148, 1998. 


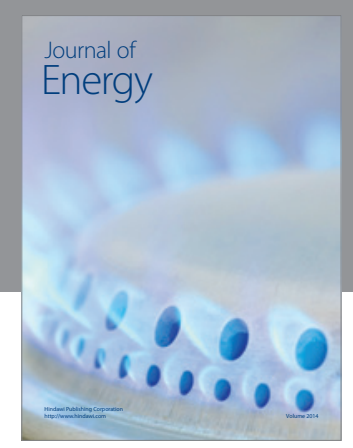

Journal of

Industrial Engineering
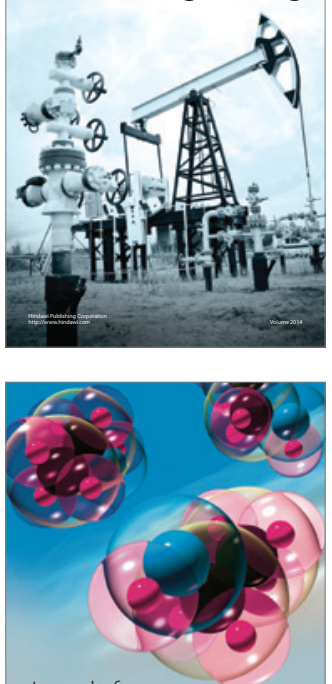

Fuels
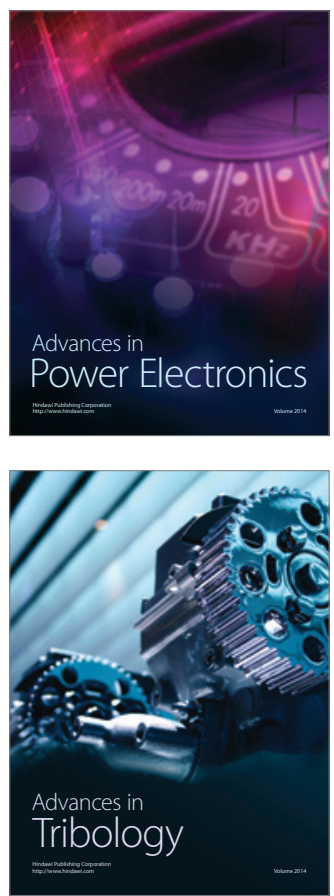

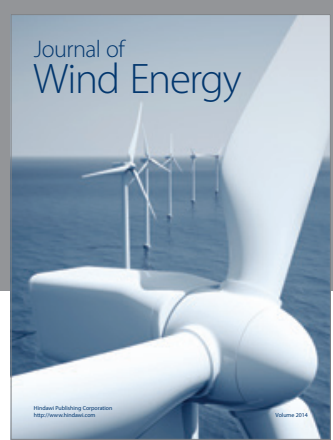

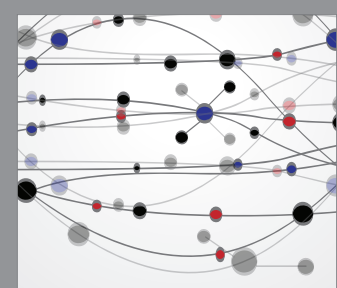

The Scientific World Journal

Submit your manuscripts at http://www.hindawi.com

Journal of

Structures
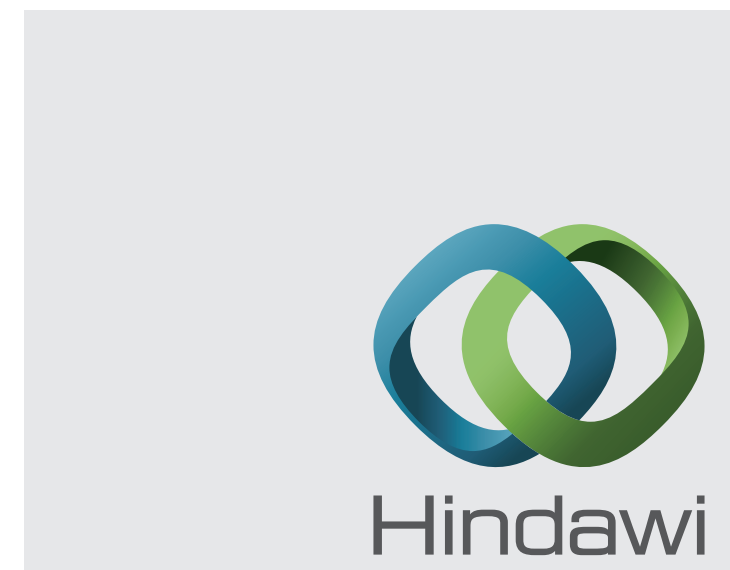

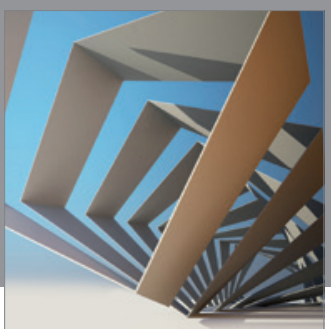

Rotating

Machinery
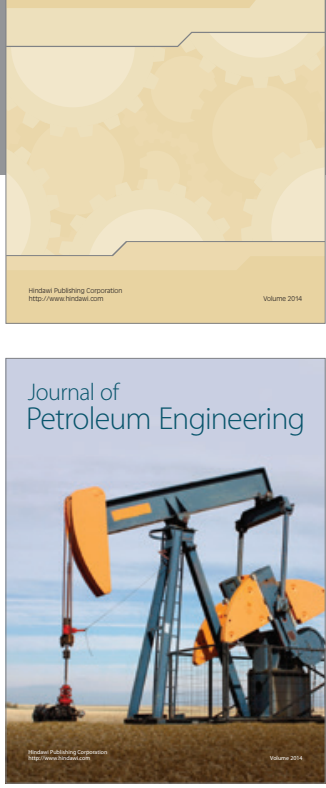

Journal of

Solar Energy
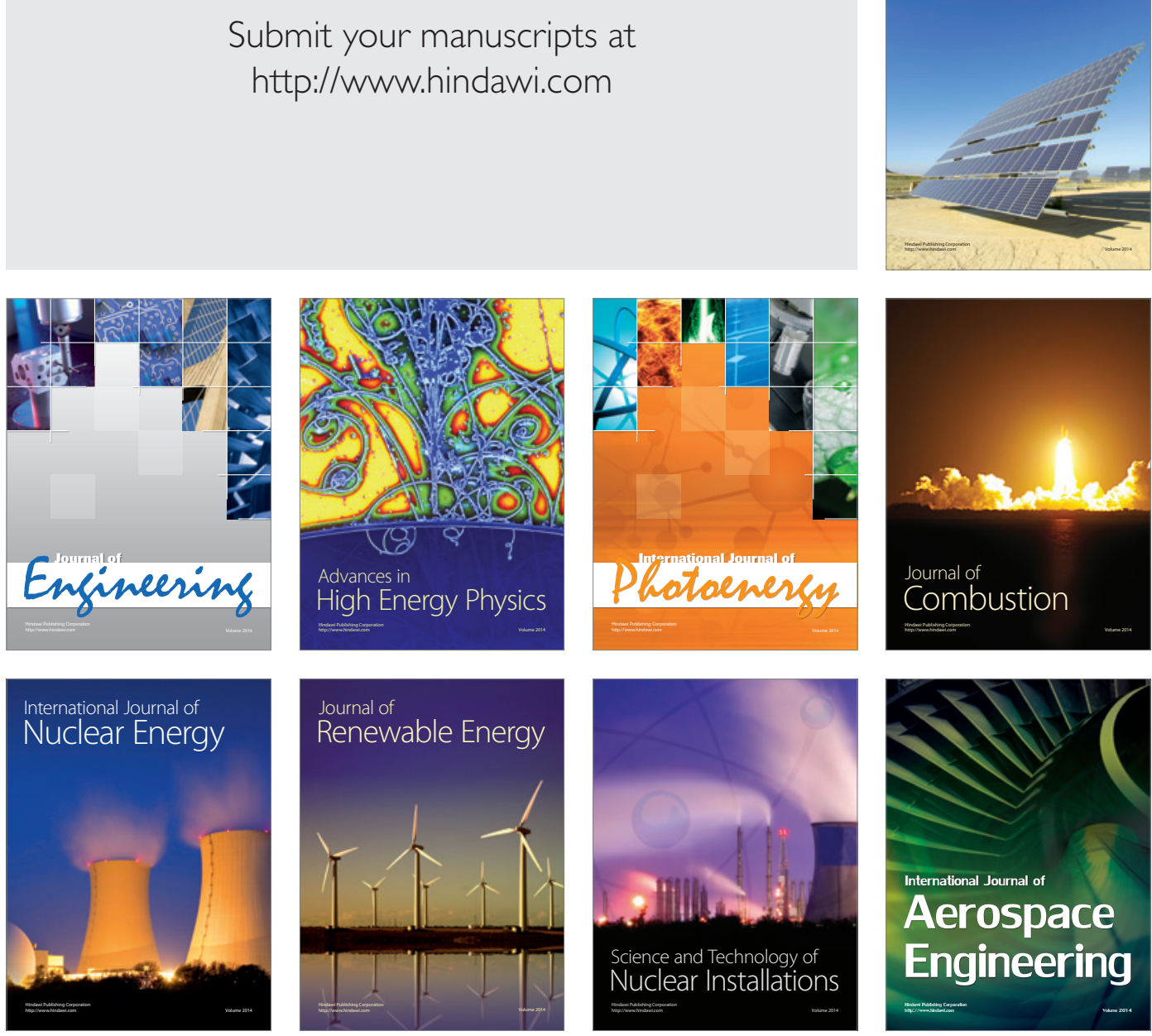